\title{
The influence of temperature, light, salinity and seed pre-treatment on the germination of Sesbania sesban seeds
}

\author{
Truong Hoang Dan ${ }^{1^{*}}$ and Hans Brix ${ }^{2}$ \\ ${ }^{1}$ Department of Environment and Natural Resources Management, College of Agriculture, Cantho University, Cantho \\ City, Vietnam. \\ ${ }^{2}$ Department of Biological Sciences, Aarhus University, Ole Worms Allé, Building 1135, 8000 Århus C., Denmark
}

Accepted 3 July, 2007

\begin{abstract}
The germination of Sesbania sesban seeds was studied under controlled environmental conditions. Interactive effects of temperature and light, effects of salinity and effects of different pre-treatments of seeds were studied. Sesbania seeds were placed in Petri dishes with filtration paper and the germination and radical development followed during seven day periods. The seeds generally germinated within one or two days. There was no difference in percent germination between dark and light treatments, but the development of radical length was significantly influenced by both light conditions and temperature. Germination was highest at 30 and $37^{\circ} \mathrm{C}$ (up to $85 \%$ ) but seeds also germinated readily at $22^{\circ} \mathrm{C}$. No germination was observed at low $\left(5\right.$ and $13^{\circ} \mathrm{C}$ ) and high $\left(45^{\circ} \mathrm{C}\right)$ temperatures. Salinities up to $100 \mathrm{mM} \mathrm{NaCl}(5.8 \mathrm{ppt})$ did not influence the germination percentage, but at 200 and $250 \mathrm{mM}$ germination was reduced to 29 and $17 \%$ respectively. Pre-treatment of seeds in hot water, sulphuric acid or calcium sulphate had only minor effect on germination rate. The results are consistent with S. sesban being an opportunistic tropical wetland species capable of establishing itself in a wide range of environmental conditions.
\end{abstract}

Key words: Temperature, light, salinity, germination, acid pre-treatment, hot water pre-treatment, Sesbania sesban.

\section{INTRODUCTION}

Sesbania sesban (L.) Merril (Fabaceae) is widely used in agriculture as green manures and as a source of forage (Anonymous, 1924; Whyte et al., 1953). The species distributes and is cultivated throughout tropical Africa and Asia (Gutteridge and Shelton, 1993). In Vietnam, the leaves of Sesbania spp. are used as forage supplied to rice straw in animal diets and mulch for home gardens in the Mekong Delta (Nao, 1983). Sesbania spp. has an extremely fast growth rate (Gutteridge and Shelton, 1993), and therefore the species may have a significant effect on wetland ecosystems.

The seed germination is often the most sensitive stage in the life cycle of a plant. Germination of wetland species

${ }^{*}$ Corresponding author. E-mail: thdan@ctu.edu.vn. Tel: 84-71830635. Fax: 84-71-830247. may be effected by several environmental factors, including diurnal temperature fluctuations, salinity, low oxygen concentration, and risk of flooding or coverage by sediments (dark environment) (Forsberg, 1966; Bonnewell et al., 1983; Meredith, 1985; Lorenzen et al., 2000; Shonjani, 2002). Esechie (1995) showed that high temperatures might have a direct adverse effect on embryo viability of Sesbania. Temperature fluctuations can have a strong interaction with seed response to light. Temperature change may interfere with the active phytochrome form (PFR) (Pons, 1992; Probert, 1992). In addition, many seeds have thick seed coats which keep water out of the seed, so the embryo cannot get the water needed to activate its metabolism and start growing (Smith and Bent, 1993). In Southeast Asia, various pre-treatments of the seeds such as nicking, hot water soaking, and physical or acid scarification have been used to enhance the germination of many legume species. 
Table 1. The result of a two-way ANOVA (F-ratios) for the effects of temperature and light on radical length and percent germination (Only data from $22^{\circ} \mathrm{C}, 30^{\circ} \mathrm{C}$ and $37^{\circ} \mathrm{C}$ treatments are used in the test as no germination occurred at lower and higher temperatures).

\begin{tabular}{|l|c|c|}
\hline Factor & Radical length & Percentage germination \\
\hline A (Temperature) & $8.09^{\star *}$ & $4.94^{\star}$ \\
B (Light) & $41.49^{\star * *}$ & 0.12 \\
A $^{*} \mathrm{~B}$ & 2.51 & 1.48 \\
\hline
\end{tabular}

$\mathrm{P}<0.05 ;{ }^{* *} \mathrm{P}<0.01 ;{ }^{* * *} \mathrm{P}<0.001$

It is important to know seed germination requirements of Sesbania, in order to understand the possible role of different environmental factors for the establishment in nature. Therefore this study was conducted to elucidate the effects of various environmental factors as well as seed pre-treatment options on $S$. sesban germination.

\section{MATERIALS AND METHODS}

\section{Seed material}

S. sesban seeds were collected in the field at An Giang province in the Southern part of Vietnam in September, 2005. Seeds of similar size were selected for the germination experiment. A seed was considered to have germinated when the radical was observed. All experiments had five replicates.

\section{Experiment 1: Effects of temperature and light}

The interactive effects of temperature $\left(5,13,22,30,37\right.$ and $\left.45^{\circ} \mathrm{C}\right)$ and light (dark and $220 \mu \mathrm{mol} / \mathrm{m}^{2} / \mathrm{sec}$ PAR) were tested in a controlled environment system at Aarhus University. Twenty seeds of uniform size were placed in a Petri dish with filter paper and ten millilitres of distilled water. The dark treatment was kept completely dark at all times by wrapping the dishes in aluminium foil and placing the Petri dishes in aluminium trays with a lid. The dark treatments were not opened until the light treatment had finished germination (after seven days). In the light treatment (12 $\mathrm{h}$ light and $12 \mathrm{~h}$ dark), all the seeds were checked daily for germination during seven days after which no seeds germinated. After seven days the lengths of primary roots were measured and the percentage germination was recorded for each treatment. Distilled water was added to the Petri dishes as necessary during the incubation to maintain saturation of the seeds.

\section{Experiment 2: Effects of salinity}

The effects of seven salt concentrations $(0,25,50,75,100,200$ and $250 \mathrm{mM} \mathrm{NaCl}$ ) at a $30^{\circ} \mathrm{C}: 20^{\circ} \mathrm{C}$ day:night cycle were tested in a controlled environment system at CanTho University. Twenty seeds of uniform size were placed in a Petri dish with filter paper and ten millilitres of different salt concentration $(\mathrm{NaCl})$. All the seeds were checked daily for germination during seven days after which no seeds germinated.

\section{Experiment 3: Effects of pre-treatment}

The effects of five different pre-treatments $\left(\mathrm{H}_{2} \mathrm{SO}_{4} 98 \%\right.$; $\mathrm{CaSO}_{4} 1$ $\mathrm{mM}$; $\mathrm{CaSO}_{4} 10 \mathrm{mM}$; soaking in $60^{\circ} \mathrm{C}$ water; soaking in $70^{\circ} \mathrm{C}$ water) at a $30^{\circ} \mathrm{C}: 20^{\circ} \mathrm{C}$ day:night cycle were tested in a controlled environment system at CanTho University. Thirty seeds of uniform size were placed in a Petri dish and the pre-treatment solutions for $10 \mathrm{~min}$. Then the seeds were rinsed with distilled water and placed in Petri dishes on filter paper and ten millilitres of distilled water. All the seeds were checked daily for germination during eight days after which no seeds germinated.

\section{Statistical analysis}

The interactive effects of temperature and light on seed germination and radical length increase were tested by a two-way analysis of variance (ANOVA) using in SPSS 10.0 for windows (SPSS Inc. Illinois, USA). Homogeneity of variances was tested using Levenes test and if necessary, data were log-transformed. Effects of salinity and the different pre-treatments were tested by one-way ANOVA. Post hoc comparisons of means were conducted by Duncans test where appropriate.

\section{RESULTS}

\section{Experiment 1: Effects of temperature and light}

Temperature had a significant effect on both radical length and percentage germination, but light condition did not affect germination (Table 1). However, light had a significant effect on radical length (Table 2). No germination was observed at the two lowest temperatures ( 5 and $\left.13^{\circ} \mathrm{C}\right)$ and at the highest temperature $\left(45^{\circ} \mathrm{C}\right)$. The maximum germination rate was observed at 30 and $37^{\circ} \mathrm{C}$. At $22^{\circ} \mathrm{C}$ the germination was slightly lower $(76 \%)$. There was no significant difference between light and dark treatment; therefore the data were pooled and presented in Figure 1.

While the percentage germination was not significantly different between 30 and $37^{\circ} \mathrm{C}$, the growth of radicals was significantly affected by temperature and light. Radical length was highest at $30^{\circ} \mathrm{C}$ and lower at 22 and $37^{\circ} \mathrm{C}$. The radical length was generally higher in the dark at all temperatures. In the light treatment, $S$. sesban seeds germinated at 22 to $37^{\circ} \mathrm{C}$ after only one day. The germination increased rapidly with time and germination was completed within a week in all treatments. The highest germination percentage was $85 \%$ at $30^{\circ} \mathrm{C}$ (Figure 2 ).

\section{Experiment 2: Effects of salinity}

Salinity significantly affected the percentage germination 
Table 2. Increase in radical length $\left(\mathrm{cm} \mathrm{day}^{-1}\right)$ of Sesbania sesban at 3 temperatures in light and dark treatments, $(\mathrm{N}=5)$;

\begin{tabular}{|l|c|c|}
\hline \multirow{2}{*}{$\begin{array}{c}\text { Temperature } \\
\left({ }^{\circ} \mathbf{C}\right)\end{array}$} & \multicolumn{2}{|c|}{ Increase in radical length } \\
\cline { 2 - 3 } & In the light $\left(\mathbf{c m ~ d a y ~}^{-1}\right)$ & In the dark $\left(\mathbf{c m ~ d a y}\right.$ da $\left.^{-1}\right)$ \\
\hline 22 & $0.38 \pm 0.13 \mathrm{ab}$ & $1.02 \pm 0.03 \mathrm{~b}$ \\
30 & $0.65 \pm 0.18 \mathrm{~b}$ & $1.26 \pm 0.05 \mathrm{C}$ \\
37 & $0.09 \pm 0.02 \mathrm{a}$ & $0.76 \pm 0.03 \mathrm{a}$ \\
\hline
\end{tabular}

Different letters in superscripts within columns indicate significant differences $(P<0.05)$ between temperatures; mean \pm standard error $(n=5)$.

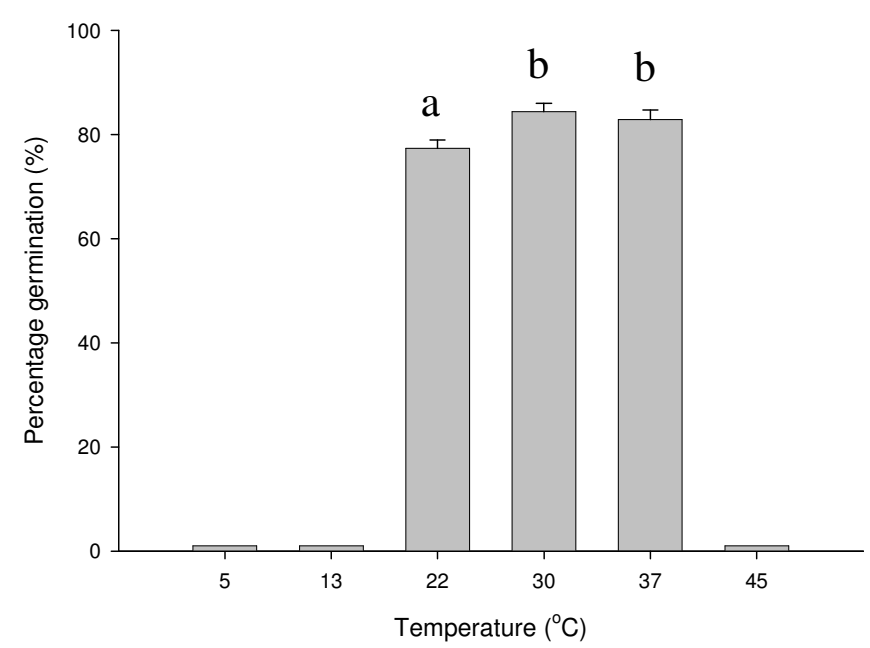

Figure 1. Percent germination of $S$. sesban seeds from light and dark treatments (pooled) at different temperatures $(n=$ 10 , mean and standard error). Different letters above columns indicate significant differences $(\mathrm{P}<0.05)$ between temperatures.

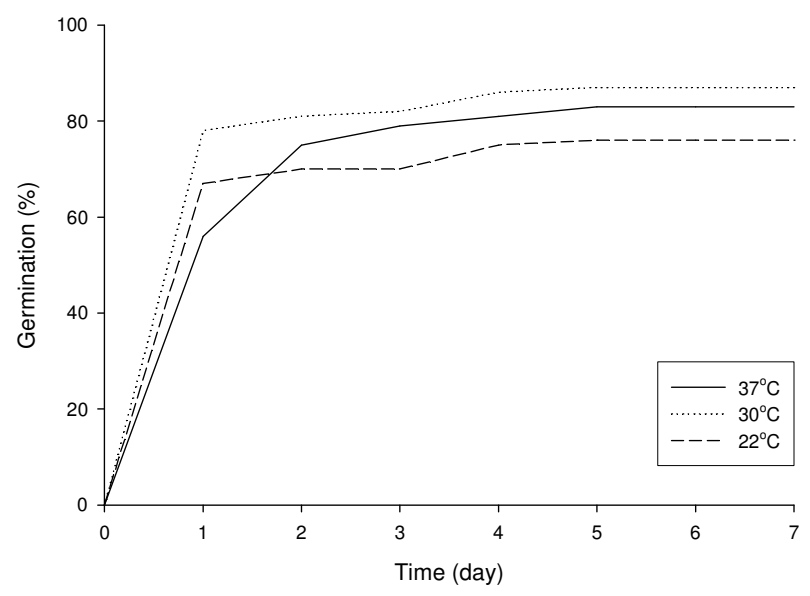

Figure 2. Average percentage germination of $S$. sesban seeds in the light treatment during seven days.

of S. sesban (Figure 3). At salinities up to $100 \mathrm{mM} \mathrm{NaCl}$ the germination rate was in the range of 41 to $50 \%$. At

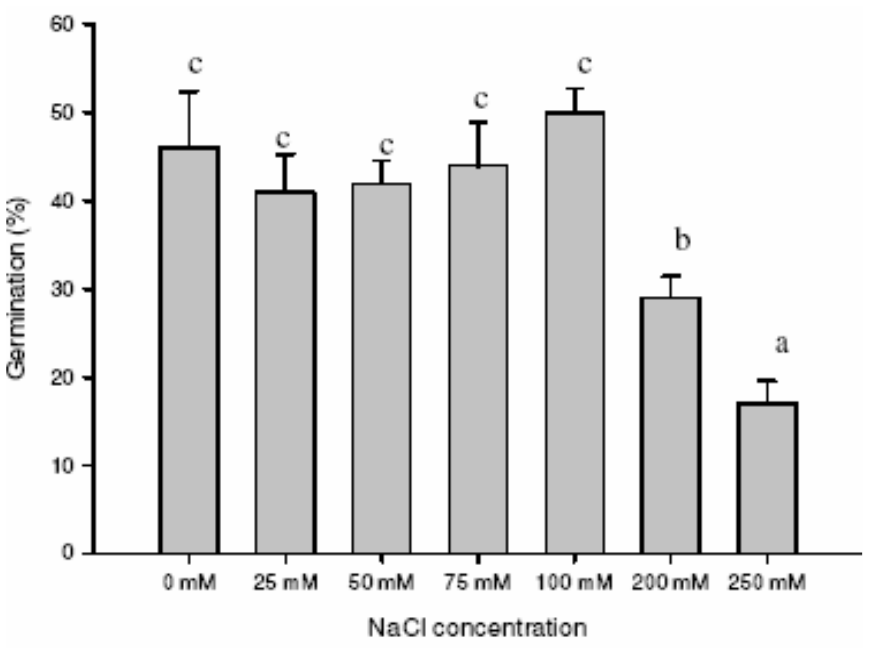

Figure 3. The effects of different $\mathrm{NaCl}$ concentrations on the germination of Sesbania sesban seeds $(n=5$, mean and standard error). Different letters above columns indi-cate significant differences $(\mathrm{P}<0.05)$ between salinities.

$200 \mathrm{mM}$ germination rate was only $29 \%$ and at $250 \mathrm{mM}$ only $17 \%$. The germination began already at day 1 at salinities up to $100 \mathrm{mM}$ but no seeds germinated until day 3 in the 200 and $250 \mathrm{mM}$ salinity treatments (Figure 4). After 3 to 4 days the germination was almost complete in all treatments and only few additional seeds germinated until day 7 when the experiment was terminated.

\section{Experiment 3: Effects of pre-treatment}

The effects of the five different pre-treatments on $S$. sesban seed germination are shown in Figure 5. The germination percentage was 37 to $53 \%$ and did not differ much between the treatments. Germination of seeds pretreated with $70^{\circ} \mathrm{C}$ hot water was significantly higher than germination of seeds pre-treated with $60^{\circ} \mathrm{C}$ water and seeds pre-treated with $98 \% \mathrm{H}_{2} \mathrm{SO}_{4}$, but generally differences were small. Germination started already day 1 in all treatments and increased the following days (Figure 6). After one week no more seeds germinated. 


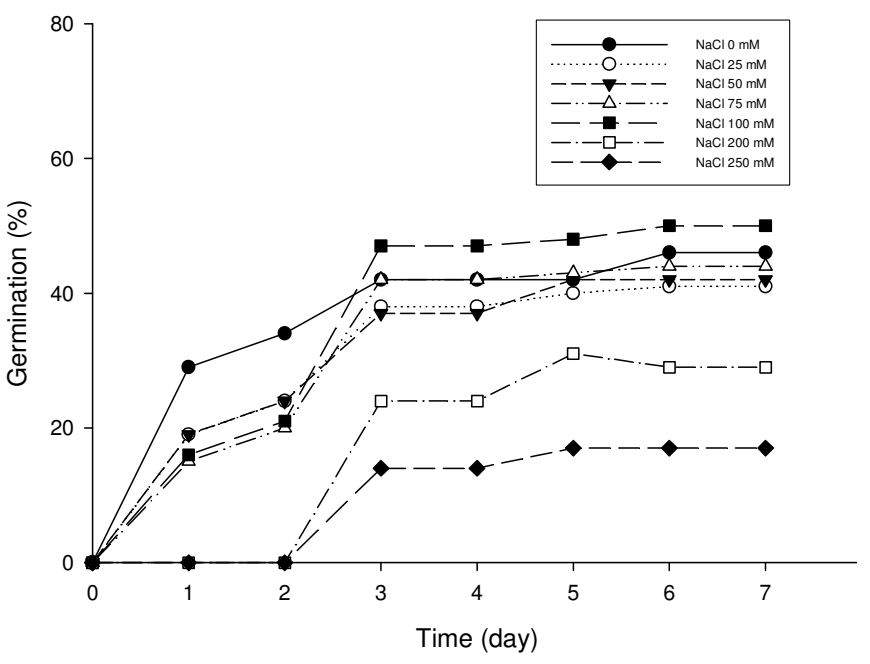

Figure 4. Percent germination of Sesbania sesban seeds at different $\mathrm{NaCl}$ salinities during seven days

\section{DISCUSSION}

The results obtained in this study show the important role of temperature for Sesbania seed germination. At high $\left(45^{\circ} \mathrm{C}\right)$ and low $\left(5\right.$ and $\left.13^{\circ} \mathrm{C}\right)$ temperatures, S. sesban did not germinate. Temperature may affect either the initial processes of water uptake by seeds or the following biochemical processes that result in cell division (Grouzis, 1988; Bewley and Black, 1978; Kermode, 1990). In the dark treatment, the results showed that, $S$. sesban can germinate without the light (Lopez and Sanchez, 1989). A study on the germination of Phalaris arundinacea, reported that there was a high germination percentage under dark conditions (38\%) and it was stated that "germination is not accelerated by light as in many other grass seeds, and may be even light inhibited in some cases" (Cisneros and Zedler, 2001). This is in agreement with the theory that phytochrome is the main sensor for light regulated seed germination. This principle allows the embryo to germinate in the absence of light (Raven et al., 1999).

Seed germination can be defined as the growth of the embryo of the mature seed, and depends on environmental conditions such as water and oxygen availability as well as temperature (Forsberg, 1966; Bonnewell et al., 1983; Meredith, 1985). Therefore, in this study, radical growth was also followed. The elongation of the radical was fastest, and the surfaces of radicals were very thin in the dark, compared to light treatment. In theory, there is a relationship between the auxin content in the embryo and the viability and the growth of radicals. The light affects the distribution of auxin, as auxin is decomposed in the light. The growth of the primary radical is stimulated by high auxin levels (Taiz and Zeiger, 1998). The observation that seeds of $S$. sesban germinated at temperatures from 22 to $37^{\circ} \mathrm{C}$ during seven days is comparable to re-

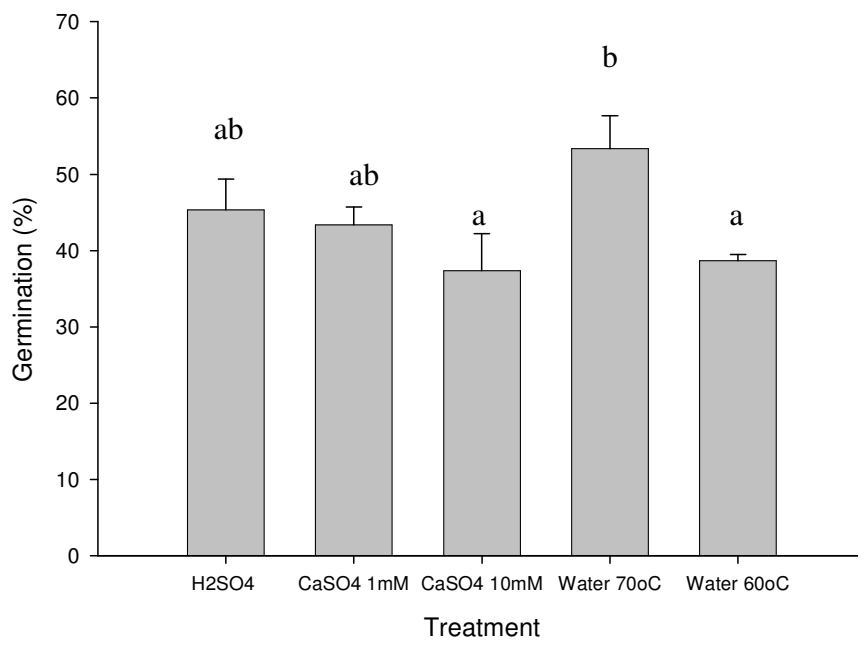

Figure 5. Effects of different pre-treatments on seed germination rate of Sesbania sesban $(n=5$, mean and standard error). Different letters above columns indicate significant differences $(P<0.05)$ between treatments.

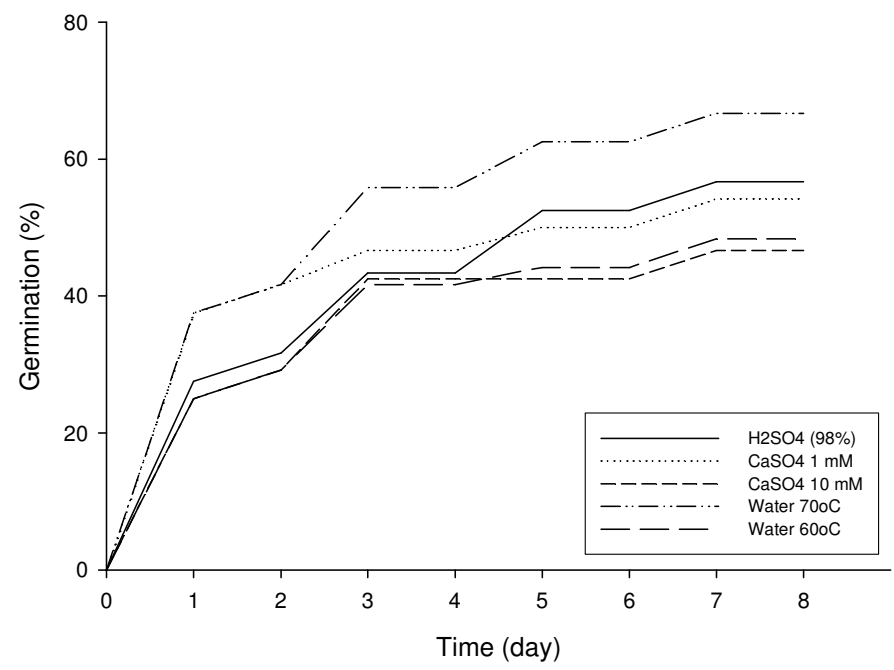

Figure 6. Percent germination of Sesbania sesban seeds exposed to different pre-treatments during eight days.

sults of other studies for this species (Cisse, 1986; Elberse and Breman, 1990; Danthu et al.,1992).

Salinities of $200 \mathrm{mM} \mathrm{NaCl}$ and higher which is equivalent to approximately $1 / 3$ strength seawater, significantly decreased the germination rate of $S$. sesban seeds. The negative water potential in saline water diminishes the influx of water into the seeds and hence impedes germination (Thompson and Grime, 1983). The reduced rate of water uptake also affects the timing of the germination. In low salinity treatments water uptake and germination occur very fast, within one to two days, whereas at high salinities germination was not recorded until after three days. High concentrations of $\mathrm{Na}$ and par- 
ticularly $\mathrm{Cl}$ ions can also have a direct toxic effect on the cells (Roundy, 1987). It must however be noted, that germination was not affected at salinities up to $100 \mathrm{mM}$ (equivalent to $5.8 \mathrm{ppt}$ ), and even at the higher 200 and $250 \mathrm{mM}$ salinities, seeds did germinate. This shows that $S$. sesban seeds are able to tolerate some salinity and germinate on slightly saline soils.

It is a common practice in Vietnam to pre-treat $S$. sesban seeds in order to enhance the germination rate of the seeds. In the present study the pre-treatment options tested only resulted in minor effects on the germination rate. Soaking seeds in hot $70^{\circ} \mathrm{C}$ water for $10 \mathrm{~min}$ increased the germination rate by approximately $20 \%$ compared to the other treatments, but germination rates (about $50 \%$ ) were generally at the same level as in the salinity experiment. The soaking of seeds in hot water is a cheap and easy method of softening the seed coat and stimulate water uptake by seeds of many tropical species (Smith and Bent, 1993). The fact that only small effects of the pre-treatments were found indicates that the $S$. sesban seed germination is not significantly restricted by a hard seed coat that inhibit water uptake.

\section{Conclusions}

Seeds of $S$. sesban generally germinate very fast (within one or two days) and under a wide range of environmental conditions. S. sesban seeds germinate readily both in the light and in the dark. The optimum germination temperature is $30^{\circ} \mathrm{C}$ to $37^{\circ} \mathrm{C}$ but germination is also efficient at $22^{\circ} \mathrm{C}$. No germination occurs at temperatures $<13^{\circ} \mathrm{C}$ and $>45^{\circ} \mathrm{C}$. Germination also occurs readily at salinities up to $6 \mathrm{ppt}$, but at higher salinities germination rates are lower. Pre-treatment in hot water, sulphuric acid or calcium sulphate to soften the seed coat has only minor effect on germination rate. The results are consistent with $S$. sesban being an opportunistic tropical wetland species capable of establishing itself in a wide range of environmental conditions.

\section{ACKNOWLEDGEMENTS}

The Danish International Development Agency (Danida) funded this work through the Cantho University University Aarhus Link in Environmental Science (CAULES) project.

\section{REFERENCES}

Anonymous (1924). Shevri as a fodder crop. Bombay Department of Land Records and Agriculture. Bulletin No. 115.

Bewley JD, Black M (1978). Physiology and Biochemistry of Seeds in Relation to Germination. 1. Development, Germination and Growth. Springer-Verlag, Berlin, Heidelberg, New York. p. 306.
Bonnewell V, Koukkari WL, Pratt DC (1983). Light, oxygen, and temperature requirements for Typha latifolia seed germination. Can. J. Bot. 61: 1330-1336.

Cisneros RL, Zedler J (2001). Effect of light on seed germination in Phalaris arundinacea L. (reed canary grass). Plant Ecol. 155: 75-78.

Cisse AM (1986). Dynamique de la strate herbacee des paturage de la zone sud sahelienne. Thèse, Université Agronomique, Wageningen, p. 212.

Danthu P, Roussel J, Dia M, Sarr A (1992). Effect of different pretreatments on the germination of Acacia senegal seeds. Seed Sci. Technol. 20(1): 111-117.

Elberse WT, Breman H (1990). Germination and establishment of Sahelian rangeland species. I. Seed properties. Oecologia. 80: 477484.

Esechie HA (1995). Partioning of chloride ion in the germinating seed of two forage legumes under varied salinity and temperature regimes. Comm. Soil Sci. Plant Anal. 26(19-20): 3357-3370.

Forsberg C (1966). Sterile germination requirements of seeds of some water plants. Physiol. Plant 19: 1105-1109

Grouzis M (1988). Structure, productivte et dynamique des systems ecologiques saheliens (Mare d' Oursi, Burkina Faso). Collection Etudes et thèses de l'ORSTOM Paris, p. 336.

Gutteridge RC, Shelton HM (1993). The scope and potential of tree legumes in agroforestry. Agrofor. Syst. 23: 177-194.

Kermode AR (1990). Regulatory mechanisms involved in the transition from seed development to germination. CRC Crit. Rev. Plant Sci. 9: 155-195.

Lopez G, Sanchez P (1989). Germinacion de dos variedades de pitaya Stenocereus griseus (Haworth) Buxbaum. Cactaceas y Suculentas Mexicans. 34: 35-40.

Lorenzen B, Brix H, McKee KL, Mendelssohn IA, Miao S (2000). Seed germination of two Everglades species, Cladium jamaiscense and Typha domingensis. Aquat. Bot. 66: 169-180.

Meredith TC (1985). Factors affecting requirements from the seed bank of sedge (Cladium mariscus) dominated communities at Wicken Fen, Cambridgehire, English. J. Biogeogr. 12: 463-472.

Nao TV (1983). Sesbania spp. in two agro-forestry systems in Vietnam. Mountain Res. Dev. 3(4): 418-421

Pons TL (1992). Seed response to light. pp 259-284 in Fenner M (Ed). Seeds. The ecology of regeneration in plant communities. CAB International, Wallingford,

Probert RJ (1992). The role of temperature in germination ecophysiology. pp. 285-325 in Fenner M (Ed.). Seeds. The ecology of regeneration in plant communities. CAB International, Wallingford.

Raven PH, Evert FR, Eichhorn ES (1999). Biology of Plants. 6th edition. WH Freedman and Company Worth Publishers, NY, USA

Roundy BA (1987). Seedbed salinity and the establishment of range plants. In: Frasier GW and Evans RA (Eds.): Seed and seedbed ecology of rangeland plants. Washington, DC: Agricultural Research Service, U.S. Dep. Agric. pp. 68-81.

Shonjani S (2002). Salt sensitivity of rice, maize, sugar beet, and cotton during germination and early vegetative growth. - Ph.D. Thesis. Institute of Plant Nutrition, Justus Liebig University, Giessen, p. 49.

Smith JM, Bent SP (1993). Dormancy and germination. Ann. Rev Plant Physiol. 30: 130-150.

Taiz L, Zeiger E (1998). Plant Physiology. 2nd edition. Sinauer Associates Ins. Publisher, Sunderland, Massachusetts, USA.

Thompson K, Grime JP (1983). A comparative study of germination responses to diurnally-fluctuating temperature. J. Appl. Eco. 20: 141156.

Whyte RO, Nilson LG, Trumble HC (1953). Legumes in Agriculture. FAO, United Nations, Rome. p. 367. 